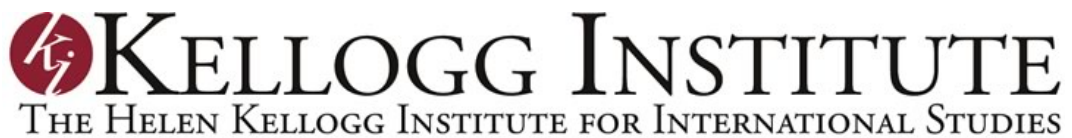

FACETS OF SOCIAL CAPITAL IN NEW DEMOCRACIES

The Formation and Consequences of Social Capital in Spain

Mariano Torcal and José Ramón Montero

Working Paper \#259 - October 1998 


\title{
FACETS OF SOCIAL CAPITAL IN NEW DEMOCRACIES The Formation and Consequences of Social Capital in Spain
}

\author{
Mariano Torcal and José Ramón Montero \\ Working Paper \#259 - October 1998
}

Mariano Torcal, a Visiting Fellow of the Kellogg Institute during spring 1997, is Associate Professor of Political Science, Universidad Autónoma de Madrid. He was a Visiting Professor in the Department of Political Science at the University of Michigan during winter 1996. He has published numerous book chapters and journal articles on political culture and democratization and the logic of cleavage formation. His article with Pradeep Chhibber, "Elite Strategy, Social Cleavages and Party Systems in a New Democracy: Spain," was awarded the 1997 Luebbert Prize for runner-up to best article in Comparative Politics. He is currently finishing a manuscript on political disaffection and democratization.

José Ramón Montero is Professor of Political Science at the Universidad Autónoma de Madrid and the Center for Advanced Study in the Social Sciences, Instituto Juan March. He has been Deputy Director of the Centro de Investigaciones Sociológicas, Director of the Economics and Social Science Program, Comisión Española de Ciencia y Tecnología, and has taught at a number of universities in Spain and the United States. A member of the European Science Foundation, he has conducted research in the fields of electoral behavior, political culture, political parties, and democratization. Among his publications are La CEDA: El catolicismo social y político en la II República (1977), El control parlamentario (1985, with Joaquín G. Morillo), and La reforma del régimen electoral (1994, with Richard Gunther et al.). He has also coedited, with Juan J. Linz, Crisis y cambio: Electores y partidos en la España de los años ochenta (1986).

The authors would like to thank Carles Boix, Jacint Jordana, Paul Whiteley, and the two anonymous reviewers for their invaluable comments on an earlier version of this paper; the Centro de Estudios Avanzados en Ciencias Sociales, Instituto Juan March, for the use of its excellent facilities; and the Comisión Interministerial de Ciencia y Tecnología (SEC95-1007) for its generous financial support. Mariano Torcal would also like to thank the Kellogg Institute at the University of Notre Dame for the financial support and excellent facilities provided during his stay as a fellow. 


\begin{abstract}
This paper examines the distinctive patterns of the formation and evolution of social trust that explain the low presence of social capital in a new democracy. Despite the increase in the number of political and social associations since the return to democracy, Spain constitutes an example of low intensity equilibrium with low levels of interpersonal trust. These low levels of trust have not changed across different generations, an attitudinal continuity that seems to be due to a certain cultural legacy transmitted from generation to generation and has proved resistant to the major economic, social, and political changes of the last few decades. The authors maintain that this transmission might be explained by the political events most Spaniards experienced and/or received from their elders during their processes of socialization. Politics matter in the creation of social capital, albeit through the filter of political socialization. The lack of trust has contributed to the low presence of social capital, and both factors have a distinctive impact on Spanish democratic politics.
\end{abstract}

\title{
RESUMEN
}

Este artículo examina los patrones distintivos en la formación y evolución de la confianza social, los cuales explican la baja presencia de capital social en las nuevas democracias. A pesar del aumento en el número de asociaciones políticas y sociales desde el retorno a la democracia, España constituye un ejemplo de equilibrio de baja intensidad con bajos niveles de confianza interpersonal. Estos bajos niveles no han cambiado entre las distintas generaciones; una continuidad actitudinal que parece obedecer a cierto legado cultural transmitido de generación en generación y que ha probado ser resistente a los importantes cambios económicos, sociales y políticos de las últimas décadas. Los autores sostienen que esta transmisión puede ser explicada por los eventos políticos que la mayoría de los españoles vivieron y/o recibieron de sus mayores durante sus procesos de socialización. La política cumple un papel importante en la creación de capital social, aunque a través del filtro de la socialización política. La falta de confianza ha contribuido a la baja presencia de capital social, y ambos factores tienen un impacto singular en la política democrática española. 
Despite the disagreement on its definition, the concept of social capital ${ }^{1}$ has become one of the most discussed topics in political science. One of the most controversial issues about social capital is how it is formed. Many scholars agree that social capital is created by the interaction with social trust: trust itself 'lubricates' cooperation and cooperation, in turn, promotes trust (Putnam 1993, 171). This model of the origins of social capital derives from Coleman (1988 and 1990) and his rational-choice approach, according to which social trust and social capital are mutually self-reinforcing. This interactive process can only reach two equilibria, a low intensity one (lack of social capital) and a high intensity one (a community of civicness). How, therefore, is it possible to pass from the low to the high equilibrium? This is not an easy question to answer. First, because the question hides a paradox commonly referred to as the bootstrap problem: "a minimal amount of social capital has to exist already, if it is to be created, since networks of obligations can be constructed and maintained only in a context in which a minimal level of trust between individuals already exists" (Whiteley 1996). Second, because a problem of collective action also exists with respect to the creation of social capital (since individuals have an incentive to free-ride on the efforts of others [Whiteley 1997, 127]), that can be modeled by a prisoners dilemma game with a stable noncooperative equilibrium (Olson 1965; Hardin 1971).

We believe that some of the most significant paradoxical problems surrounding the creation of social capital center on the concept of social trust and the axiomatic interactive relationship between them defended by some scholars. From a rational-choice perspective, social trust is a relational and rational action that can be produced by a rational calculation, although not always fully calculated, of a tit-for-tat nature in which one good turn is repaid with another of equal value (Coleman 1988, 102; Levi 1996a, 3). ${ }^{2}$ Thus, following this reasoning, social trust will increase in a given society by the creation of a network of political and social organizations of tit-for-tat nature. In contrast, as some scholars have argued (Newton 1998), social trust in modern societies is fundamentally a leap of faith built on very imperfect knowledge. But social trust is not blind, it involves the accumulation and updating of experience with organizations and associations. Therefore, social trust could also be a cultural attitude created by the accumulation of experience and socialization previous to the tit-for-tat game situation,

1 There are two main approaches to the definition of social capital. Coleman's (1990) definition is a structural one, that is, social capital is an aspect of a social structure that facilitates any sort of social relation providing a source of collective action. Therefore, it is created by the participation of individuals but it is not an attribute of individuals (Kolankiewicz 1996). Other authors, however, define social capital as a subjective phenomenon composed of a range of values and attitudes (Newton 1997). In this paper we have used the first definition.

2 The contribution of the new institutionalism to the conceptualization of trust from the rationalchoice perspective has been remarkable. See, for instance, Grief (1994) and Weingast (1995). 
conditioning the marginal utilities of the preferences. ${ }^{3}$ Accordingly, the creation of new institutions or organizational settings may not produce an axiomatic increase in social trust.

The analysis of social capital in new democracies could be very enlightening in this respect. At the outset of these democracies there might often be virtually no social capital: their citizens have been exposed to long experiences of authoritarian rule during which associative life was, at best, discouraged or repressed, or both. Successful transitions imply the creation or restoration of a set of democratic institutions, rules, and practices, but to what extent does this new institutional framework give rise to social trust and social capital? We maintain that institutional change and democratic politics may foster the creation of social capital to a certain degree, but that there still might not be enough to break a situation of low intensity equilibrium. This outcome seems evident in the light of the persistently weak associative and political life found in some countries with stable democracies like Spain (Torcal 1995; van Deth 1996). The instauration and development of new democratic institutions do not per se create social capital beyond a level of low intensity equilibrium. Any increase in social capital in these new democracies is conditioned by the attitudinal presence of trust among citizens. Whereas new democratic institutions may create the roots of social capital, the rate of this change is determined, as we hope to show, by intergenerational differences in the extent to which citizens trust each other. We also maintain that face-to-face interactions hardly constitute the driving force behind rising social capital in new democracies, above all because these interactions are rare and irregular outside small voluntary organizations. A preexisting level of trust among individuals has to exist and, as Whiteley argues (1996), socialization is instrumental in the creation of social trust and, hence, in any significant increase in the levels of social capital. In order to escape from situations of low intensity equilibrium, therefore, there must be a major intergenerational change in levels of trust. However, as the second part of our argument attempts to show, to try to create social trust by socializing citizens is not as axiomatic as some authors claim. Trust is not an automatic by-product of either economic or social modernization or regime change. Rather, it is much more strongly influenced by citizens' preadult political experiences, contacts, or public discourses related to whatever kind of organizational and institutional life may have existed at that time, as well as by the majoritarian content of their cultural transmission. Contrary to what Putnam (1993) assumes, ${ }^{4}$ politics may play a significant

3 In contrast to social capital, social trust is an individual feature, although collectively recreated in any given society. Here we have measured this individual characteristic using a traditional indicator of interpersonal trust.

4 However, in a recent article on the United States, Putnam (1995) discusses the positive role played by the government in the creation of social capital. 
role in forming social capital (Levi 1996b, 50-51), although through the mediation of political socialization and its impact on social trust.

In this paper we examine the problems for the formation of social capital in a new democracy and their consequences for levels of political involvement. Thus, we begin by assessing the current situation of social capital in Spain through an analysis of ecological and survey data and in comparison with a number of behavioral and attitudinal indicators related to membership in secondary organizations in Western European countries. This comparative analysis shows that despite the increase since the instauration of democracy, social capital in Spain remains in a low intensity equilibrium. In the next section we briefly consider the problem posed by the formation of social trust and use cohort analysis to show that the existing levels of social trust in Spain are explained by specific patterns of intergenerational transmission. Cohort analysis proves that whilst, for instance, the strength of democratic legitimacy has changed remarkably across generations, the low levels of interpersonal trust have been transmitted from generation to generation. This suggests that the evolution of the political attitudes and orientations in which social capital is grounded has scarcely been affected by the economic, social, and political transformations of the last three decades. Finally, we will analyze the most important consequences of this weak social trust for social capital and political involvement. ${ }^{5}$

\section{Social Capital in Spain: Some Comparative Data}

Organizational life was extremely weak in Spain at the end of Francoism (Linz 1971). By the beginning of the political transition two important developments should have increased Spanish associative life. On one hand, the economic growth, educational change, and social modernization that began in the sixties should have fuelled the emergence of more associations. On the other, the political transition to democracy, which required the creation of parties and other political or ideological organizations, together with the new climate of freedom, should have fostered the creation of associations of all kinds. Indeed, this seems to have happened, as figures for the number of associations created each year since 1968 show (Figure 1). ${ }^{6}$ With the consolidation of Spanish democracy in the early eighties, the number of new associations continued to grow at an apparently ever faster rate. At first glance, therefore, social capital

5 Before starting, we should emphasize that this paper is eminently empirical in nature. It is largely based on survey data, most of which have been taken from the Data Bank of the Spanish Centro de Investigaciones Sociológicas (CIS). Other survey data come from the Centro de Estudios sobre la Realidad Social (CIRES), the 1980 European Values Survey, and the 1990 World Values Survey.

6 These figures have been taken from the Register of Associations; we would like to thank Mr. Angel García del Valle for facilitating our access to these data. 
seems to have been increasing in Spain since the outset of the democratic regime, and it also seems to have achieved a high intensity equilibrium responding to the setting of new democratic institutions.

Figure 1

New Associations per Year in Spain, 1968-1995

Nevertheless, the number of associations is certainly an unsatisfactory indicator of organizational strength: it tells us nothing about the membership of the different organizations, the intensity of their involvement, or the frequency of their activities. Above all, it is impossible to know if and when an organization has effectively ceased to exist, surviving merely as an item in the official register. But Figure 1 is not without interest. First, it shows the impressive scale of organizational expansion during this period of almost thirty years. Between 1968, when only 5,650 associations were listed, and 1995, a cumulative total of no fewer than 156,019 new 
organizations were registered, that is, almost thirty times more than the original number. This increase is no less remarkable if we consider it in relation to the growth of the Spanish population in the same period. A simple associativity index reflecting the number of organizations per 100,000 inhabitants clearly shows the extraordinary leap in this period: from 18.4 in 1968 to 293.9 in $1995 .{ }^{7}$ Second, it is possible to identify distinct waves in the rhythm of creation: slow during the final years of Francoism, intense during the period of the transition to democracy, steady during the eighties, and relatively intense again after 1990. The crucial years were, naturally, those of political change; over 21,000 new associations were registered between 1977 and 1980 alone, that is, more than all those created in the preceding twelve years, or the equivalent of a $220 \%$ increase with respect to 1976 . The third interesting aspect is the territorial scope of the organizations. At present two out of three are local and one out of four provincial; regional organizations account for only some $9 \%$ of the total, whilst only $8 \%$ operate nationwide. As was to be expected, the consolidation of the new decentralized state since 1980 has encouraged the formation of regional organizations through the federation of local and provincial ones. Although the number of national federations has increased more recently, the Spanish associative fabric is still characterized by its localism, the weak links among similar organizations, and the deficient communication among them all (Prieto-Lacaci 1994, 202-3). Finally, the nature of their activities should be considered. According to the criteria employed by the Register of Associations, almost $40 \%$ of the total are classified as cultural or ideological, $15 \%$ educational, and a further $15 \%$ sports or youth organizations. Economic and professional associations account for $6 \%$, family and consumer groups $5 \%$, and philanthropic organizations $4 \%$. It should be noted that whilst the number of cultural and ideological organizations has grown consistently as a proportion of the total over the past decade, the others have shrunk.

As has been stated above, this type of data casts no light on the levels of membership of the different associations or the political attitudes connected with associative engagement. Nor do these data provide any information about the number of 'living' organizations, that is, those that in practice define the density of the associative fabric at any given moment. Some indication of this, however, may be gained by examining the affiliation rates of the Spanish political parties and trade unions. Those of the political parties are amongst the lowest in Europe (Montero 1981; Bartolini 1983). At the end of the 1980s the ratio of members to electors was 10.5 in Western Europe as a whole; Spain, with a ratio of just 2.0, ranked last in the European league table (Katz, Mair, et al. 1992, 333; Morlino 1995, 332). The ratio between the members and voters of the different parties is also extremely low. In the 1996 general elections the Popular Party (PP) and

7 The index rose relatively steadily: 22.8 in $1970,36.0$ in 1975, 107.68 in 1981, 178.33 in 1986, 287.71 in 1991. See also Linz (1971). 
the Socialist Party (PSOE) won almost 19 million votes; yet their combined memberships amounted to only some 900,000. The very low levels of party affiliation in Spain accord with the Spaniards' even weaker propensity to play an active role in the parties, with the parties' scant organizational penetration of society, and with the weakness of party identification among the electorate.

Much the same is true of the unions. Spain and France share the lowest European indices of union density, calculated as the proportion of active and unemployed wage earners affiliated to unions (Price 1989; Ebbinghaus and Visser 1997). As was to be expected, the recognition of union liberty and the formation of numerous labor organizations in 1977 led to a spectacular, confusing, and short-lived increase in union membership. This immediately dropped sharply but has slowly been increasing again since the end of the 1980s as a result of the economic cycle, closer collaboration among the different union federations, and their greater functional autonomy from the parties and economic actors (Astudillo 1998). In 1994 the Spanish union density rate was $17.2 \%$ (Jordana 1996). Spanish workers' reluctance to join unions has created a paradoxical situation for the two main union federations, the Unión General de Trabajadores (UGT) and Comisiones Obreras (CC OO). Whilst they enjoy both considerable institutional recognition in the political arena and hegemony in the large companies, their presence and influence are much weaker in the small- and medium-sized companies that are precisely the largest category of firms.

Survey data offer a more complete picture of the nature and dimensions of social capital in Spain. In general terms these data show that levels of membership and participation in voluntary associations, intermediary organizations, and new social movements in Spain are relatively low as compared to most other Western democracies. As can be seen in Table 1, Spaniards are less likely to belong to or work in voluntary organizations than citizens in any of the other countries selected. ${ }^{8}$ This is not only true of political parties and trade unions but of all the many organizations of civil society that depend on the voluntary participation of citizens. Furthermore, even though the number of associations has risen in recent years, these data show that the levels of participation by Spaniards in these organizations have basically remained stable since the early eighties. Sixty-nine percent did not belong to any organization in $1981,66 \%$ in 1990 , and $68 \%$ in 1994 . According to a 1993 survey, fully $76 \%$ of Spaniards did not belong to any organization but, more importantly, only $18 \%$ declared that they belonged to one

8 The list of associations and organizations that respondents were asked if they belonged to comprised 10 items in 1981, 16 in 1990, and 12 in 1994. The percentages in Table 1 were calculated by recoding the variables measuring membership as 0 (do not belong) and 1 (belong) and then creating a new variable adding from the sum of them all. The percentages for voluntary work were computed in the same way. 
organization, $5 \%$ to two, $2 \%$ to three, and just $1 \%$ to more than three (Gunther and Montero 1996 , 28).

Table 1

Membership and Voluntary Work in Voluntary Organizations in Western Democracies, 1981 and 1990

\begin{tabular}{|l|c|c|c|c|c|}
\hline Countries $^{\text {a }}$ & \multicolumn{2}{|c|}{ Membership } & \multicolumn{2}{c|}{ Voluntary Work } \\
\hline & 1981 & 1990 & & 1981 & 1990 \\
\hline Iceland & -- & 89 & & -- & 44 \\
\hline Netherlands & 62 & 83 & & 27 & 44 \\
\hline United States & -- & 69 & & -- & 44 \\
\hline W. Germany & 50 & 65 & & 73 & 29 \\
\hline Belgium & 42 & 56 & & 21 & 27 \\
\hline Austria & -- & 52 & & -- & 29 \\
\hline Great Britain & 52 & 50 & & 22 & 20 \\
\hline Ireland & 66 & 48 & & 22 & 26 \\
\hline Denmark & 62 & 46 & & 54 & 21 \\
\hline France & 27 & 36 & & 15 & 21 \\
\hline Italy & 26 & 33 & & 17 & 22 \\
\hline Portugal & -- & 32 & & -- & 18 \\
\hline Spain & 31 & 20 & & 23 & 7 \\
\hline
\end{tabular}

a Countries are listed in decreasing averages of both years.

Percentages represent those who declare themselves to be members and do voluntary work in at least one organization.

Sources: 1981 European Values Survey and 1990 World Values Survey

Of course, it may be argued that survey data do not reflect the real level of voluntary associationism. If this were the case, one would expect it to be a transnational phenomenon. Yet this does not alter the fact that significant differences are found in the data for the various Western European countries. Furthermore, the comparatively low level of participation in voluntary associations in Spain is not only confirmed by the ecological data discussed above but also by other reliable survey items, for example, voluntary work or financial support for such organizations (Baumgartner and Walker 1988). The information given in Table 1 clearly shows 
that the gap between Spanish citizens and other Europeans is even greater with respect to the amount of voluntary work done for these associations (see also van Deth 1996). ${ }^{9}$

On the other hand, it has been argued (Pérez Díaz 1996, 40-41) that the strength of Spanish civil society lies in the rise of voluntary associations of a 'societal nature' (consumer, human rights, ecological, and tenants' organizations, etc.). Nevertheless, data from the 1990 World Values Survey reveal low levels of membership and involvement across the whole gamut of organizations-ecological, peace, human rights, youth, sport and recreational, cultural and artistic groups-as well as community associations. In fact, Spain ranks among the Western countries with the lowest levels of membership of societal organizations. in 1990 some $88 \%$ of Spanish respondents declared that they did not belong to any of organizations of this type. ${ }^{10}$ Therefore, the lack of participation in traditional organizations such as parties and unions has not been compensated for by involvement in these new associations. The evolution of membership by organizations since the early 1980 s confirms this weakness. As can be seen in Table 2, the decrease in membership of unions and religious organizations has not been accompanied by any noticeable increase in the societal associations, with the exception of those related with sporting or festive activities (Orizo 1996, 120-121).

The relatively low level of associative life in Spain accords with a series of attitudinal and behavioral characteristics that, as we will demonstrate below, are related to social capital. One of these characteristics is the relatively low level of interpersonal trust. The data shown in Table 3 suggest that Western democracies may be divided into two groups in terms of the strength or weakness of interpersonal mistrust. Spain lies on the border line that separates the countries in which distrusters formed a clear majority in 1990. In $198161 \%$ of Spaniards stated that they mistrusted their fellow citizens, a level similar to that found in Belgium and only surpassed in France and Italy. In 1990 the difference between these two groups of countries had widened;

9 We agree with Gundelach (1995) that grassroots activity should be measured by more sophisticated instruments, especially in the case of the new type of associations in which membership is not so important. However, as we have seen in Table 1, the distribution of people stating that they do some voluntary work is little different. Furthermore, as is discussed by Maloney (1996), not all new forms of participation (for example, checkbook membership) produce social capital. Moreover, we consider that assessments of social capital levels should include membership of more traditional organizations such as political parties and unions. As has often been noted, they could well produce more social capital than bowling clubs and sport clubs (Boix and Posner 1996; Tarrow 1996).

10 The order of the other countries was as follows: Portugal, $82 \%$; Italy, $80 \%$; France, $73 \%$; Austria and Great Britain, 72\%; Ireland, 66\%; Belgium, 61\%; United States, 60\%; West Germany and Iceland, 54\%; Denmark, 49\%; and The Netherlands, 33\%. This is the sum cumulative percentage of those who declare that they are not members of any educational-cultural, human rights, third world aid, ecological, peace, or youth organization, sports or leisure club, animal rights organization, or local voluntary association to fight poverty, unemployment, homelessness, or race discrimination. 
along with the French and Belgians, the Southern Europeans formed a distinctive group among the Western democracies. This point should be emphasized. Besides being low, the level of interpersonal trust in Spain has remained basically stable over time. This is even more striking if one considers the political, cultural, social, and economic changes of the last three decades. In the early 1970s only two out of ten Spaniards felt they could trust their fellow citizens (López Pintor 1982, 158). Twenty years later this figure had changed little: only one third of the population affirms its trust in other people (Table 4).

Table 2

Membership in Voluntary Associations in Spain, 1981-1996 (In percentages)

\begin{tabular}{|c|c|c|c|c|}
\hline Organizations & 1981 & 1990 & 1994 & 1996 \\
\hline Parties & 3 & 1 & 2 & 2 \\
\hline Trade unions & 11 & 5 & 6 & 5 \\
\hline Religious & 15 & 6 & 7 & 6 \\
\hline Sports & -- & 5 & 9 & 10 \\
\hline Leisure & -- & -- & 11 & -- \\
\hline Charities & 5 & -- & 7 & -- \\
\hline Cultural & 5 & 4 & 7 & 8 \\
\hline Youth & 3 & 1 & 2 & 4 \\
\hline Human rights & 1 & 1 & 2 & -- \\
\hline Ecological & -- & 1 & 2 & -- \\
\hline Women & -- & 1 & 1 & -- \\
\hline Peace & -- & 1 & 1 & -- \\
\hline Voluntary work & -- & -- & -- & 5 \\
\hline Neighbors & -- & -- & -- & 11 \\
\hline None & 69 & 66 & 68 & 64 \\
\hline$(\mathrm{N})$ & $(2,303)$ & $(2,637)$ & $(5,087)$ & $(2,481)$ \\
\hline
\end{tabular}

Sources: For 1996, Centro de Investigaciones Sociológicas (CIS) Data Bank; for other years, Orizo $(1996,135-40)$ 
Table 3

Interpersonal Mistrust in Western Democracies, 1981 and 1990

(Percentages of those who declare not trusting other people)

\begin{tabular}{|l|c|c|}
\hline Countries $^{\text {a }}$ & $\mathbf{1 9 8 1}$ & $\mathbf{1 9 9 0}$ \\
\hline Portugal & -- & 76 \\
\hline France & 71 & 72 \\
\hline Italy & 72 & 62 \\
\hline Belgium & 63 & 61 \\
\hline Spain & 61 & 62 \\
\hline W. Germany & 58 & 51 \\
\hline Ireland & 56 & 52 \\
\hline Great Britain & 54 & 55 \\
\hline Iceland & -- & 54 \\
\hline United States & -- & 47 \\
\hline Netherlands & 49 & 44 \\
\hline Denmark & 44 & 40 \\
\hline
\end{tabular}

${ }^{a}$ Countries are listed in decreasing averages of both years.

Sources: 1981 European Values Survey and 1990 World Values Survey.

Table 4

Interpersonal Trust in Spain, 1980-1996

(In percentages)

\begin{tabular}{|l|c|c|c|c|c|c|}
\hline & 1980 & 1981 & 1987 & 1990 & 1994 & 1996 \\
\hline Trust & 22 & 33 & 25 & 32 & 29 & 34 \\
\hline Not trust & 74 & 61 & 73 & 62 & 67 & 61 \\
\hline DK, DA & 4 & 6 & 2 & 6 & 4 & 5 \\
\hline$(\mathrm{N})$ & $(1,200)$ & $(2,303)$ & $(2,499)$ & $(4,147)$ & $(2,491)$ & $(2,481)$ \\
\hline
\end{tabular}

Sources: For 1981 and 1990, European Values Survey and World Values Survey, respectively; for other years, CIS Data Bank.

Thus, social capital in Spain has increased since the return to democratic politics. As has been seen above, the number of associations has increased exponentially; just over one million Spaniards belong to political parties, and about two million workers are trade union members. 
This evolution has been accompanied by a small increase in the levels of interpersonal trust. However, new organizations are mostly local, fragmented, and probably enjoy only a short life. Parties and unions were virtually nonexistent at the beginning of the democratic regime, and over the last twenty years only three out of ten Spaniards have belonged to any type of association. ${ }^{11}$ Furthermore, two out of three Spanish citizens consistently express distrust towards their fellow citizens. It is clear that after the natural upsurge in associative life provoked by the transition to democracy, social capital in Spain has failed to develop beyond a situation of low intensity equilibrium.

\section{The Formation of Social Capital: Politics Matter}

We have already noted that the situation of low intensity equilibrium that characterizes social capital in Spain has persisted despite the major political, institutional, and economic changes of the last two decades. Contrary to what is generally assumed (for instance by Levi [1996a]), democratic regimes per se do not produce social capital. In fact the Spanish case shows that the full functioning of democratic politics does not result in an axiomatic increase in social capital. In order to explain this paradoxical outcome, we think that attitudinal factors should be taken into account. More particularly, the evolution of social capital in new democracies is conditioned by the attitudinal presence of trust among citizens. Democracy may create social capital, but the rate of change is dependent on the extent to which different generations harbor different levels of interpersonal trust.

In order to substantiate this claim, we have analyzed the evolution of trust through a longitudinal research design. Our basic tool is cohort analysis. It is well known that a longitudinal cohort design can detect three different effects that explain attitudinal change or stability. First, it can identify a cohort effect: some attitudes reflect consistent and enduring generational differences and are hardly changed by specific political events. The second is a period effect: some opinions or attitudes vary in all generations as a result of an event affecting all of them at the same time, without this necessarily giving rise to a lasting or consistent attitudinal shift. The third is the life-cycle effect: some attitudes change as a cohort grows older. If the analysis of

11 We must point out that in Spain the influence of unions and other social and political organizations on the society goes beyond their members, creating or changing public opinion and political mobilization against the government. Membership in these organizations, measured by survey data, does not reflect this important associational presence. However, the influence of these organizations is very fragmented, depending heavily on the issue and the sectors of the society affected and very short lived (related to the media attention span). This may be a topic for research, but perhaps the public visibility of some small organizations may encourage more to free-ride on the efforts of others. 
social capital by cohorts reveals life-cycle effects, it would reinforce the argument that attitudes are acquired through a continuous learning process, lasting from adolescence into old age. ${ }^{12}$ In this case, life-cycle effects would mean that social trust increases as citizens age. The existence of period effects, in turn, would demonstrate that the level of social capital in Spain has varied as a result of political mobilization and the increasing numbers of associations created from the top: face-to-face interactions would thus have been the main source of at least temporary social trust. Finally, cohort effects would demonstrate the importance of preadult socialization for the creation of social trust.

For the purposes of this cohort analysis we have identified six generations of Spaniards, defined in accordance with the most significant historical events of this century (Torcal 1995). ${ }^{13}$ As we will see in more detail below, the first notable finding is that social trust shows a dominant cohort effect, despite the presence of some small period effects. The next question is therefore to determine the extent to which these attitudes vary in the different generations. In other words, we must measure the size of these differences. If differences among generations are constant but quantitatively small, then we can conclude that there has been hardly any cultural change as result of intergenerational replacement and that these small differences reflect significant cultural continuity and hence intergenerational transmission. On the other hand, if the differences among generations are constant and also quantitatively important, then there will be good grounds to argue that these changes in political attitudes in the population as a whole are result of a process of generational replacement.

Before examining social trust, a cohort analysis of education may perhaps be of some interest for illustrative purposes. Social modernization and public policies have fuelled an increase in educational levels in Spain in recent decades (Núñez 1992, 166-78). This tendency,

12 More specifically, it has been argued that whilst young people see politics as remote and irrelevant, these same individuals become more interested in politics as they mature and acquire greater social and economic responsibilities (Nie, Verba, and Kim 1974).

13 The six generations have been defined as follows. The oldest cohort comprises all those born before 1922, who reached adulthood at the end of the Monarchy, during the Second Republic or the Civil War. The next cohort (cohort 5), which has been labeled the generation of autarky, consists of those people born between 1923 and 1937, who reached political maturity during the difficult years of the economic depression. The fourth group (cohort 4) is that of the economic take-off and includes those born between 1938 and 1952, who came of age when economic control passed from the Falangists to the technocrats, who went on to implement the Stabilization and Development Plans of the sixties. The third group (cohort 3 ) is that of the liberalization of the regime: those born between 1953 and 1962 acquired political consciousness during the liberalization and crisis of the dictatorship. The second group (cohort 2) is that of the transition and is made up of those born between 1963 and 1967, who reached political maturity during the political transition to and consolidation of the new democratic system. Finally, the youngest cohort consists of all those born since 1968, who have only known a fully fledged democratic regime. 
however, has not affected all Spaniards equally; the younger generations have benefited most from rising education. Moreover, this is a phenomenon that should have a clear generational effect, since education is mainly acquired during the first two decades of an individual's life and tends to remain constant thereafter. Hence, educational levels should display an extremely stable cohort effect, with major generational differences indicated by significant distances among the curves of the various cohorts. Figure 2, which presents data on the level of education for each cohort, reveals that the younger the cohort, the higher the proportion of individuals who have completed at least secondary education. This figure also shows that the qualitative change in educational levels occurred precisely between the fourth and third generations, that is, between the generation that experienced the economic take-off after the hard years of autarky and the generation that enjoyed the prosperity that followed the stabilization plans, the limited liberalization of the authoritarian regime and, most importantly, the expansion of the university system. Thus, a cohort analysis of education clearly shows the relevance of intergenerational change in Spaniards' educational levels; at the same time, it confirms the reliability of this type of longitudinal research design. An examination of educational levels also shows that cohort analysis can detect whether or not intergenerational differences are significant. It is not enough merely to identify a cohort effect. this must be accompanied by an analysis of its magnitude, that is, of the quantitative differences among generations.

Generational effects can also be observed with regard to interpersonal trust. But in contrast to what was found with respect to education, there are very few differences among generations. Despite the dramatic changes that have taken place in Spain over the last thirty years, the lack of social trust has been transmitted from one generation to another virtually intact.

As can be seen clearly in Figure 3, the intergenerational variations in the proportion of Spaniards reporting that they trust other people are very small and do not respond to the patterns of intergenerational change observed in the levels of education. It seems, therefore, that the political, social, and economic transformations of the last few decades have not substantially altered the extent to which Spaniards trust their fellow citizens. Furthermore, social trust does not appear to evolve as a function of the life cycle. In other words, trust in others does not increase with aging. Note that in Figure 3 there is no progressive increase in all the curves. Finally, social trust hardly shows any periods effects. The general pattern appears to have remained remarkably stable over time; more importantly, the small period effect observed in 1990 neither coincided with a particular moment of political change and mobilization nor led to any noticeable increase in the number of associations. These results confirm the hypothesis that interpersonal trust is the result of a long-standing process of cultural accumulation and that it tends to remain 
stable across generations. ${ }^{14}$ As a result social capital is not disseminated in Spanish society. The mere proliferation of associations does not create social capital. It may be a necessary condition but it is not a sufficient one. Participation in voluntary associations requires the widespread diffusion of social trust throughout a slow process of political socialization. Significantly, even the liberalization of the authoritarian regime and the return to democracy do not seem to have fostered a process of adult learning to trust others or to participate. The absence of interpersonal trust forms part of an entrenched cultural heritage transmitted from generation to generation. Furthermore, there are no signs of a positive change among the youngest cohorts.

Figure 2

Education by Cohorts, 1978-1994

(Percentage of those who have completed High School or more)

Source: CIS Data Bank

14 For the concept of cultural accumulation, see Almond and Verba $(1963,213-21,279)$ and Putnam (1993, 152-62). 
This conclusion should not be interpreted as another type of cultural or historical determinism. We do not think it is necessary to go back to earlier centuries in Spanish history in order to explain the current lack of social capital among different generations of Spaniards. Rather our explanation is based on the more recent historical events that occurred before the transition to democracy. Moreover, these events are fundamentally political. ${ }^{15}$ We argue, therefore, that politics also matter for the formation of social capital in the recent past (albeit mediated by the influence of political socialization) and that politics should be brought 'back in' to the model.

\section{Figure 3}

\section{Interpersonal Trust by Cohorts, 1980-1994}

(Percentages of those who trust people)

\section{Source: CIS Data Bank}

15 We maintain that Putnam's argument about the origins of social capital in Italy may not only be historically inaccurate (Sabetti 1996) but, as Laitin $(1995,172-3)$ and Tarrow $(1996,393)$ point out, it also ignores many equally political and historical events that have taken place in Italy over the centuries (see also Boix and Posner 1996, 20-5). 
Political and social conditions in Spain over the last 150 years have scarcely favored the development of voluntary associations. First, political life has been characterized by an extraordinary discontinuity. In the twentieth century alone a liberal monarchy has been followed by a short military dictatorship, a democratic republic that ended in a bloody civil war, and the establishment of the Francoist regime which, along with that of Salazar in Portugal, was the most protracted of the first postwar European dictatorships. Political instability obstructed the development of autonomous social organizations, of traditions of cooperation between social and political elites, and of relations based on mutual trust among citizens. Moreover, regime discontinuity was accompanied by the fragility of political parties and the intense turnover among party elites. Economic backwardness also contributed to the weakness of Spanish social organizations, the deficient articulation of the demands of many social groups, and the scant influence of modernizing social leaders as opposed to those of the powerful traditional oligarchies. The monarchical Restoration, which lasted from the end of the nineteenth century through the first third of the twentieth century, saw the consolidation of what Linz $(1981,367)$ has identified as the principal characteristic of interest politics in Spain: the primacy of politics over interests, of partisan cleavages over interest conflicts, of political alignments over economic interests. This posed evident difficulties for the institutionalization of interest organizations and the consolidation of voluntary associations. These problems were only aggravated by systematic electoral fraud, the extensive functioning of caciquismo, and the increasingly widespread feeling of alienation from the political system. During the thirties the short democratic experience of the Second Republic was dominated by mass membership of social and political organizations as the result of intensive mobilization but also by the extreme politicization of these organizations' strategies and interests, their alignment with the parties in all the many conflicts that surfaced during these years, and by growing polarization in the articulation of their demands. Once again, therefore, the political climate prevented the institutionalization of interest group politics, as well as the diffusion of cooperative mechanisms beyond the ever more exclusive political identities. ${ }^{16}$ After the Civil War the first fifteen years of the authoritarian regime saw the virtual elimination of most of the existing organizational traditions, the repression of opposition groups, and the imposition of a rigid interventionist framework for those voluntary associations that were able to emerge or survive. During this period only those organizations linked to the Catholic Church or the single party were able to operate with any degree of autonomy. In 1961 there were only 8,329 officially registered voluntary associations (Linz 1971), a figure that alone is sufficiently

16 For a clear theoretical argument about the risk of having highly mobilized political organizations and associations in the context of a very fragmented society, see Boix and Posner (1996). 
eloquent as to the weakness of the associative fabric in Spain. This historical background helps to explain the lack of social trust and participative attitudes among older Spaniards.

From the 1960s onwards, however, a number of significant changes began to take place that might have fostered the creation of social capital at least among the youngest generations. In 1964 the authoritarian regime introduced a Law of Associations which broke the virtual duopoly previously enjoyed by the single party and the Church. This enabled the regime to channel a limited development of social, lato sensu, organizations. Ten years later the democratic transition necessarily required the creation of parties and political organizations, whilst the new climate of liberties fostered the creation of associations of all kinds. However, as we have seen in Figure 3, these two developments did not significantly foster attitudes of interpersonal trust either among the youngest Spaniards or among the older cohorts. Two facts may account for this outcome. On one hand, the previous authoritarian regime waged an intense and repetitive propaganda campaign against any kind of organizational life and political involvement beyond the hierarchical structures provided by the state. As a result there was only a minority who were politically mobilized either against or in favor of the regime: the great majority of Spaniards only wanted progress and stability at the outset of the new political regime (Aguilar 1996). On the other hand, the Spanish transition was mainly achieved by elite settlements reached through negotiations among the most influential political figures (Linz 1993; Gunther 1992). At some points during the transition there were important political mobilizations. But these tended to have short-term goals and were discouraged as soon as the elites reached agreement, meaning that there was no time for participation to become institutionalized. These political events should have, therefore, facilitated the intergenerational transmission of attitudes favoring low levels of social trust and political involvement. ${ }^{17}$

If this is the case, how can we explain the majoritarian democratic support that Spaniards have consistently given to their new democracy? Contrary to what we have seen with respect to social trust, the preferences of each generation for a democratic regime have varied substantially. We argue that politics have an impact on this change too. A generation-by-generation comparison of preferences for the democratic regime reveals a clear cohort effect (Figure 4). ${ }^{18}$ The differences between each generation and the next are stable and considerable-even between the third cohort (born between 1950 and 1958, which came of age during the period just before the transition to democracy) and the fourth (born between 1933 and 1949, which experienced the most rapid period of economic growth and enjoyed increasing educational levels

17 For a similar argument, see Álvarez Junco (1994); and for detailed empirical evidence, Torcal (1997).

18 For the sake of clarity, Figure 4 does not show the pattern of the youngest cohort, which is almost identical to that of cohort 2. 


\section{Figure 4}

\section{Legitimacy by Cohorts, 1980, 1994}

(Percentage of those who declare that democracy is preferable)

Source: CIS Data Bank

during its formative years). The younger the cohort, the greater the support given to the democratic regime, although those differences tend to be smaller among the youngest cohorts. It should also be noted that this intergenerational change in the levels of support for the new regime is found not only between the third and fourth cohorts; changes are also evident between the fourth and the fifth cohorts which preceded them. Those intergenerational variations reveal the distinct learning experiences about democratic politics of the different cohorts, which were closely 
related to different collective memories of the breakdown of the Second Republic and the resulting civil war. As Aguilar (1996) has shown, these memories have had an identifiable impact on different generations, conditioning their interpretation of the Francoist regime and, more importantly, of the political changes that followed it. In this respect, Spaniards were ready to support democracy once it was achieved. Their support was already considerable in 1980, reflecting the existence of a range of attitudes favorable to democracy even before the start of the political transition (Montero, Gunther, and Torcal 1997; Maravall 1995, 275). But not everybody was equally disposed to accept the change. The oldest generations, those who had personally experienced the collapse of the 1930s, expressed less support for democracy at the time, and have lagged behind other generations in this respect ever since.

The roots of both the weakness of social trust and the majoritarian support for democracy may be traced back into the recent past. But these two attitudes have evolved very differently: although two decades of democratic life have reinforced support for the regime, they do not appear to have substantially altered social trust. In contrast to what has been said by some classic authors (Dahl 1971, 30-2; Converse 1969) and maintained more recently by some social capital theorists (Coleman 1990; Putnam 1993), the functioning of democratic institutions does not always generate per se political attitudes such as cooperation and trust. The Spanish case seems to demonstrate that the two set of attitudes-democratic legitimacy and interpersonal trust-can be independent. Table 5 clearly shows that there is no relationship between them. Whereas democratic legitimacy has evolved as a result of processes of political learning during the authoritarian regime and of adult resocialization during the early phases of the system, interpersonal trust has maintained similarly low levels across different generations as a consequence of processes of cultural accumulation, which transmit images of political experiences crystallized under earlier regimes and which are periodically revitalized through feelings about politics contoured by cynicism, disaffection, and alienation (Montero, Gunther, and Torcal 1997; Maravall 1995, 290-291).

\section{Social Trust and Some of Its Consequences}

We have already argued that the low levels of social trust in Spain are mostly the result of the accumulation of negative experiences, contacts, and public discourses related to any kind of associational or organizational life existing during childhood and transmitted through generations of Spaniards. In this section we are going to analyze the extent to which this lack of trust affects social capital and political participation. In the case of the former, we should be able to examine

the impact of social trust on the levels of membership of social and political organizations. The classic hypothesis suggests that the two are closely linked (Almond and Verba 1963, 212-27; 


\section{Table 5}

Democratic Legitimacy and Interpersonal Trust in Spain, 1996

(In percentages)

\begin{tabular}{|l|c|c|}
\hline Preference towards & Trusters & Nontrusters \\
\hline Democracy & 89 & 82 \\
\hline Dictatorship & 8 & 9 \\
\hline Indifference & 3 & 9 \\
\hline (N) & $(831)$ & $(1,442)$ \\
\hline
\end{tabular}

Source: CIS Data Bank

Putnam 1993, 99-116). To what extent is this true in Spain? To test this hypothesis we have carried out a logistic regression analysis of survey data from $1996^{19}$ in which the dependent variable is membership in any social or political organization. ${ }^{20}$ The independent variables are social trust and four standard sociodemographic variables (age, gender, education, and occupation). The model obtained, shown in Table 6 , is statistically significant, but the overall prediction of the model is only $64 \%$ (the pseudo R-square is .03). Hence, it tells us very little about the explanation for membership of these organizations, though we can at least conclude that social trust is statistically significant (with a coefficient of .199 and an odds ratio of 1.22). It seems clear, therefore, that the probability of becoming a member of one of these organizations increases with the existence of social trust. This relationship is found even when the standard sociodemographic variables are included in the model. Consequently, these results show that attitudes such as the lack of interpersonal trust also help to explain the relative scant presence of social and political organizations. Finally, we should emphasize the lack of statistical significance

19 This survey was carried out by the Centro de Investigaciones Sociológicas (CIS) in June, 1996 , to a representative sample of 2,481 Spaniards.

20 Originally the dependent variable was a simple sum scale reflecting the number of organizations to which each respondent belonged to in 1996. These organizations were neighborhood associations, youth associations, mothers groups, sports clubs, trade unions, voluntary work associations, political parties, cultural associations, and religious organizations. This variable was in fact a count event variable that presented a poisson distribution. However, we decided to convert it into a dummy variable with values of 1 (member of at least one organization) and 0 (no membership). The results of the poisson regression and of the logistic regression were very similar; for the sake of simplicity we only give those of the logistic regression. Since it has been argued that the strength of Spanish civil society lies in the growing number of voluntary associations of a 'societal nature' (Pérez Díaz 1996, 40-1), we decided to repeat the analysis with associations of that type. The results were also very similar. 
of age. This confirms once again that social capital, this time measured through membership of voluntary organizations, is equally absent in each and every generation of Spaniards.

Table 6

Interpersonal Trust and Membership in Voluntary Associations in Spain, 1996 (Logistic Regression)

\begin{tabular}{|l|c|c|}
\hline \multicolumn{1}{|c|}{ Independent Variables } & Coefficients & Odds Ratios \\
\hline Social trust & $.199^{\star}$ & 1.22 \\
\hline Age & -.001 & 1.0 \\
\hline Gender & .198 & 1.22 \\
\hline Education & $.273^{\star}$ & 1.31 \\
\hline \multicolumn{1}{|c|}{ Occupation } & & \\
\hline Housewife & Reference & .719 \\
\hline Retired & -.328 & 1.1 \\
\hline Unemployed & .102 & 1.06 \\
\hline Student & .062 & .941 \\
\hline Work & -.061 & \\
\hline Intercept & -1.350 & \\
\hline
\end{tabular}

Dependent Variable: membership in voluntary associations Overall Prediction of the model $65 \% \quad$ Pseudo R-square .03 Log-likehood $-1452.2119 \quad{ }^{*}$ Significant at $p<0.05$

Source: CIS Data Bank.

Previous data have demonstrated the influence of low social trust in the scant presence of social capital among Spaniards. The question is, then, what are the effects of these two variables on political participation? Some of the comparative literature has also highlighted the effects of social capital on political participation and involvement (Moyser and Parry 1996; van Deth 1996; Hooghe and Derks 1997). Putnam himself $(1995,68)$ has argued that the fall in social capital in the United States has resulted in a citizenship that is less psychologically engaged with politics. The effect of social capital on different levels of political involvement and participation could also have an impact on government responses and policy agenda-setting. As Rosenstone and Hasen (1993) have demonstrated in the American case, the differential mobilization of the population has led to very particularistic demands. And according to Hardin (1993), those who trust are better off both economically and politically speaking. Is this also the case in Spain? We believe that social capital (formed in part through social involvement) has a 
clear direct impact on political involvement, corroborating what van Deth $(1997,12)$ has called the direct model of the effects of social involvement on political involvement. We should start to test this assertion by measuring the impact of social capital on political participation.

We should begin by recalling that the level of conventional participation is much lower in Spain than in other Western democracies. In terms of the well-known indicators of conventional participation used by Barnes, Kaase, and others (1979), Spaniards participate less in those activities that require the least effort (for instance, 'reading the political section of the newspaper' or 'discussing politics'), although the gap shrinks and even disappears in terms of more demanding activities (Montero and Torcal 1990; Maravall 1984, 117). These differences have hardly changed during the 1980 s and early 1990s (Torcal 1995) and are confirmed by the proportion of respondents who stated that they had participated in at least one of the conventional activities (besides voting) included in the 1990 World Values Survey (Table 7). Spain has the lowest levels of conventional participation in the whole of Western Europe. Moreover, these low levels of participation cannot be explained in terms of preferences for alternative forms of participation related to the so-called 'new politics' (Kaase and Barnes 1979; Dalton 1988). In any case, Spain also has one of the lowest levels of unconventional participation of all the Western European democracies. Along with the Belgians, Spaniards are among the least likely to have participated in any of the four types of unconventional activities considered in the survey.21

Is this lack of participation related to low levels of social capital? To answer this question we have created indices of conventional and unconventional participation as dependent variables containing the frequency of participation in eight different political activities. ${ }^{22} \mathrm{~A}$ factor analysis of these data (not shown) produced two very different factors for the two types of participation, conventional and unconventional, with which we have created the two dependent variables. ${ }^{23}$ The set of independent variables included was similar in both models: social trust, membership

21 Respondents were asked whether they had participated in any of the following four activities: signing a petition, joining a boycott, participating in demonstrations, and joining strikes.

22 The data come from the same CIS 1996 survey data that was already mentioned in Table 6. The activities were following political news; talking about politics; trying to convince others; working to solve a problem that affects you or your community, town or city; and working for a party or a political candidate.

23 We have performed a factor analysis with varimax rotation, producing two clear factors that explain 58 and $26 \%$ of the variance respectively. The first factor was formed from conventional participation activities such as following political news; talking about politics; trying to convince others; working to solve a problem that affects you or your community, town or city; and working for a party or a political candidate. The second factor includes unconventional participation activities: attending political rallies, blocking the traffic, and occupying buildings, factories, or other public spaces. Both dependent variables, conventional and unconventional participation, were created with the factor scores respectively resulting from two principal component analyses based on the previous results of the factor analysis. 
of voluntary associations (social capital), self-placement on the left-right ideological scale, and the standard sociodemographic variables (with the exception of occupation, which consistently has been shown to have no effect).

Table 7

Conventional and Unconventional Political Participation in Western Democracies, 1981 and 1990

\begin{tabular}{|l|c|c|c|c|c|}
\hline \multicolumn{1}{|c|}{ Countries $^{\text {a }}$} & \multicolumn{2}{c|}{ Conventional } & & \multicolumn{2}{c|}{ Unconventional } \\
\hline & $\mathbf{1 9 8 1}$ & $\mathbf{1 9 9 0}$ & & $\mathbf{1 9 8 1}$ & $\mathbf{1 9 9 0}$ \\
\hline Norway & 78 & 89 & & -- & -- \\
\hline W. Germany & 79 & 84 & & 85 & 88 \\
\hline Denmark & 80 & 78 & & 78 & 81 \\
\hline Sweden & 78 & 79 & & -- & -- \\
\hline Iceland & 76 & 79 & & -- & 93 \\
\hline Netherlands & 74 & 76 & & 80 & 86 \\
\hline United States & 67 & 73 & & -- & 93 \\
\hline Great Britain & 64 & 66 & & 92 & 91 \\
\hline France & 62 & 65 & & 81 & 85 \\
\hline Spain & 69 & 52 & & 73 & 66 \\
\hline Ireland & 52 & 59 & & 77 & 83 \\
\hline Italy & 51 & 58 & & 80 & 87 \\
\hline Belgium & 45 & 54 & & 64 & 77 \\
\hline
\end{tabular}

Percentages of those who participate in at least one of the activities besides voting

${ }^{a}$ Countries are listed in decreasing averages of conventional participation.

Sources: 1981 European Values Survey and 1990 World Values Survey

Table 8 contains the results of a multiple regression analysis in which conventional participation is the dependent variable. The results reveal that the two variables that are the center of our analysis, that is, social trust and social capital (measured by membership of voluntary associations), have a statistically significant relation with the index of conventional participation: that is, the greater the presence of social capital and social trust, the greater the probability of using any of the mechanisms of conventional participation. This relation holds even when we control for the effect of other variables, such as education, gender, and age. If the standardized coefficients of regression are compared, membership of voluntary organizations is 
found to be the best predictor. Of the sociodemographic variables included in the model, the relation with education (.202) and gender (.145) should be noted. These coefficients reveal that less educated citizens and women are least likely to engage in conventional forms of participation, confirming that the distinct structure of opportunities for some specific social groups is an important differentiating factor in Spanish politics. In short, conventional participation may depend on a series of attitudes and sociodemographic variables, but it also depends on the level of social capital. It should be noticed that the R-square of the model is only 0.148 , which is rather low. But if we include in the model other attitudinal variables related to social capital, such as interest in politics, the model improves to 0.31 without altering the relationships presented in Table 8. Social capital, therefore, has a clear direct impact on conventional political participation.

Table 8

Social Capital and Conventional Political Participation in Spain, 1996 (OLS Estimators)

\begin{tabular}{|l|c|c|}
\hline \multicolumn{1}{|c|}{ Independent Variables } & Coefficients & Betas \\
\hline Social trust & $.163^{*}$ & .08 \\
\hline $\begin{array}{l}\text { Membership in voluntary } \\
\text { associations (social capital) }\end{array}$ & $.487^{\star}$ & .238 \\
\hline Ideology & $-.002^{\star *}$ & -.048 \\
\hline Age & $.001^{\star *}$ & .057 \\
\hline Gender & $.289^{*}$ & .145 \\
\hline Education & $.152^{*}$ & .202 \\
\hline \hline Intercept & $-.766^{*}$ & \\
\hline \hline R-squared & 0.148 & \\
\hline
\end{tabular}

Dependent Variable: conventional participation

* Significant at $p<0.01$

Source: CIS Data Bank

** Significant at $\mathrm{p}<0.05$

It might be thought that the weakness of social capital, contrary to what has been observed with respect to conventional mechanisms, would strengthen the predisposition for unconventional participation. The comparative literature has shown that the decrease in conventional participation in the advanced democracies over the last few decades has often been linked to a search for alternative forms of participation (Kaase and Barnes 1979, 532-3; Inglehart 1990, 369-70). Has this also been the case in Spain? The results presented in Table 9, in which unconventional political participation is the dependent variable, reject this hypothesis. Moreover, 
the signs of the coefficients for the social capital and social trust indicators are the same as those observed for conventional participation; that is, the higher the levels of social trust and social capital, the higher the level of unconventional participation. The model presented in Table 9 fits even better, since the R-square in this case is 0.206 (and 0.26 when interest in politics is included). Membership of voluntary associations is the best predictor of the dependent variable after ideology and education. Social trust is also statistically significant. These data are therefore relevant to our understanding of why Spaniards are comparatively unlikely to participate in politics regardless of the costs attributed to it, the different structure of opportunities for social sectors, the levels of education, and the intensity of ideological polarization.

Table 9

\section{Social Capital and Unconventional Political Participation in Spain, 1996}

(OLS Estimators)

\begin{tabular}{|l|c|c|}
\hline \multicolumn{1}{|c|}{ Independent Variables } & Coefficients & Betas \\
\hline Social trust & $.08^{* *}$ & .039 \\
\hline $\begin{array}{l}\text { Membership in voluntary } \\
\text { associations (social capital) }\end{array}$ & $.224^{*}$ & .108 \\
\hline Ideology & $-.09^{*}$ & -.198 \\
\hline Age & $-.095^{*}$ & -.272 \\
\hline Gender & $.132^{*}$ & .065 \\
\hline Education & $.08^{*}$ & .115 \\
\hline \hline Intercept & $.689^{*}$ & \\
\hline \hline R-squared & 0.206 & \\
\hline
\end{tabular}

Dependent Variables: unconventional participation

* Significant at $p<0.01 \quad$ ** Significant at $p<0.05$

Source: CIS Data Bank.

\section{Concluding Remarks}

This paper has examined the distinctive patterns of the formation and evolution of social trust that explain the low presence of social capital in a new democracy. Despite the increase in social capital since the return to democracy, Spain constitutes an example of a low intensity equilibrium. We argue that this is a result of the low levels of interpersonal trust found among Spaniards. These levels have not changed across different generations, an attitudinal continuity 
that seems to be due to a certain cultural legacy transmitted from generation to generation and that has proved resistant to the major economic, social, and political changes that have taken place over the last few decades. We also maintain that this transmission might be explained by political events that most Spaniards experienced and/or received from their elders during their processes of socialization. Politics matter in the creation of social capital, albeit through the filter of political socialization. The lack of trust has contributed to the low presence of social capital, and both factors also have a distinctive impact on democratic politics. Political participation (both conventional and unconventional) in Spain is very low and highly unequal (Torcal 1997). While this could be the subject of a different paper, we will end this one by asserting that the weakness of social capital is an important contributory factor to both the low levels of political participation and the political inequality related to them. Therefore, the causal model we can defend with the evidence presented here states the following: the accumulation of political experiences with organizations and institutions during childhood in a authoritarian regime (political socialization) influences the absence of social trust, which hardly changes with other political experiences during adulthood; these low levels of social trust generate a low presence of social capital; and finally, the low levels of social capital prevent political involvement. Regime change, i.e., new institutional setting and organizations, may create some social trust and social capital but never beyond a low level intensity equilibrium.

It is true that young people currently appear to be responsible for a certain revitalization of some associations, notably those related to sporting and social-charitable activities as well as to human rights and ecological issues. Some increase in the level of acceptance of the new social movements has also been observed, although it seems to be rather less intense than in recent years (Orizo 1996, 120-3). Equally, it is possible to detect increasing sentiments of solidarity, accompanied by more voluntary work in what is a growing network of nongovernmental organizations (Casado 1992). But these trends, the evolution of which naturally remains to be seen, contrast with the irregularity of the day-to-day activities of many social movements, their relative isolation, and the limited response to their appeals. It is, as Álvarez Junco (1994, 439) has observed, a somewhat schizophrenic situation for social movements. They are incapable of winning sustained social support in the midst of the weak associative fabric and generalized interpersonal mistrust that characterize Spanish society. But they can occasionally emerge from periods of apathy and abandon when circumstances favor their conversion into vehicles of protest against governments which are held responsible for all society's problems and which may be used as excuses for the passivity of many social groups. It is clear that the influence of Spanish political and social associations goes beyond their members, contributing to create public opinion and protesting against the government, but this type of influence does not constitute social capital. 
This paper is more than just a study of the formation of social trust and its influence on social capital in Spain. It is a discussion of the formation of social capital in a new democracy. Many authors have sought an understanding of this problem in the rational-choice approach. In fact, the literature consists of yet another search for a solution to the noncooperative equilibrium inherent in the problem of collective action that is also found in the formation of social capital. (For instance, the argument of selective incentives, the appropriation of private goods, the prisoner's dilemma supergame, induced institutional equilibrium, and so on have all been used to this end). We maintain that the explanation of the existence of free-riding in the formation of social capital may be found in the lack of social trust. But social trust is not only an action resulting from rational calculations of a tit-for-tat nature; it can be also a cultural attitude resulting from the accumulation of socializing experiences. This definition of social trust not only helps to explain the very low rates of increase of social capital in new democracies after their authoritarian experiences but also helps to resolve the bootstrap problem. The presence of this attitude may change the marginal utility of the cooperative preference among actors, resolving the noncooperative equilibrium to the prisoner's dilemma inherent in collective action.

\section{References}

Aguilar, Paloma. 1996. Memoria y olvido de la guerra civil española. Madrid: Alianza.

Almond, Gabriel A. and Sidney Verba. 1963. The Civic Culture: Political Attitudes and Democracy in Five Nations. Princeton: Princeton University Press.

Álvarez Junco, José. 1994. "Movimientos sociales en España: Del modelo tradicional a la modernidad postfranquista" in Los nuevos movimientos sociales: De la ideología a la identidad, Enrique Laraña and Joseph Gusfield, eds. Madrid: Centro de Investigaciones Sociológicas.

Astudillo, Javier. 1998. "Los recursos del socialismo: Las cambiantes relaciones entre el PSOE y la UGT (1982-1993).” Instituto Juan March, Madrid, PhD dissertation.

Barnes, Samuel H. and Max Kaase, et al. 1979. Political Action: Mass Participation in Five Western Democracies. Beverly Hills: Sage.

Bartolini, Stefano. 1983. "The Membership of Mass Parties: The Social-Democratic Experience, 1889-1978" in Western European Party Systems, Hans Daalder and Peter Mair, eds. London: Sage.

Baumgartner, Frank R. and Jack L. Walker. 1988. "Survey Research and Membership in Voluntary Associations." American Journal of Political Science 32: 908-28. 
Boix, Carles and Daniel N. Posner. 1996. "Making Social Capital Work: A Review of Robert Putnam's Making Democracy Work: Civic Traditions in Modern Italy." The Center for International Affairs, Harvard University, paper 96-4

Casado, Demetrio, ed. 1992. Organizaciones voluntarias en España. Barcelona: Editorial Hacer.

Coleman, James S. 1988. "Social Capital in the Creation of Human Capital." American Journal of Sociology 94: 95-119.

1990. Foundations of Social Theory. Cambridge: Harvard University Press.

Converse, Philip E. 1969. "Of Time and Partisan Stability." Comparative Political Studies 2: 139-71.

Dahl, Robert A. 1971. Poliarchy, Participation and Opposition. New Haven: Yale University Press.

Dalton, Russell J. 1988. Citizen Politics in Western Democracies: Public Opinion and Political Parties in the United States, Great Britain, West Germany and France. Chatham: Chatham House Publishers.

Ebbinghaus, Bernhard and Jelle Visser. 1997. "When Labour Institutions Matter: Union Growth and Decline in Western Europe, 1950-90." Paper presented at the European Sociological Association Conference, University of Essex.

Grief, Avner. 1994. "Cultural Beliefs and the Organization of Society: A Historical and Theoretical Reflection on Collectivist and Individual Societies." Journal of Political Economy 102: 912-45.

Gundelach, Peter. 1995. "Grass-Roots Activities" in The Impact of Values, Jan W. van Deth and Elinor Scarbrough, eds. Oxford: Oxford University Press.

Gunther, Richard. 1992. "Spain: The Very Model of the Modern Elite Settlement" in Elites and Democratic Consolidation in Latin America and Southern Europe, John Higley and R. Gunther, eds. Cambridge: Cambridge University Press.

Gunther, Richard and José Ramón Montero. 1996. "Spain." Paper presented at the Conference on Comparative National Election Project, Instituto Juan March, Madrid.

Hardin, Russell. 1971. "Collective Action as an Agreeable N-Prisoner's Dilemma." Behavioral Science 16: 472-81. 1993. "The Street Level Epistemology of Trust." Politics and Society 21: 505-29.

Hooghe, Mark and Anton Derks. 1997. "Voluntary Associations and the Creation of Social Capital." Paper presented at the ECPR Joint Sessions, Bern.

Inglehart, Ronald. 1990. Culture Shift in Advanced Industrial Society. Princeton: Princeton University Press.

Jordana, Jacint. 1996. "Reconsidering Union Membership in Spain, 1977-1994: Halting Decline in a Context of Democratic Consolidation." Industrial Relations Journal 27: 211-24. 
Kaase, Max and Samuel H. Barnes. 1979. "In Conclusion: The Future of Political Protest in Western Democracies" in Political Action: Mass Participation in Five Western Democracies, S. H. Barnes, M. Kaase, et al., eds. Beverly Hills: Sage.

Katz, Richard S., Peter Mair, et al. 1992. "The Membership of Political Parties in European Democracies, 1960-1990." European Journal of Political Research 22: 329- 45.

Kolankiewicz, George. 1996. "Social Capital and Social Change." The British Journal of Sociology 47: 427-41.

Laitin, David P. 1995. "The Civic Culture at 30." American Political Science Review 89: 173-86.

Levi, Margaret. 1996a. "A State of Trust." EUI Working Paper 96/23. European University Institute, San Domenico.

1996b. "Social and Unsocial Capital: A Review Essay of Robert Putnam's Making Democracy Work." Politics and Society 24: 45-55.

Linz, Juan J. 1971. "La realidad asociativa de los españoles" in Sociología española de los años 70. Madrid: Confederación Española de Cajas de Ahorros.

1981. "A Century of Politics and Interests in Spain" in Organizing Interests in Western Europe: Pluralism, Corporativism and the Transformation of Politics, Suzanne D. Berger, ed. Cambridge: Cambridge University Press.

. 1993. "Innovative Leadership in the Transition to Democracy and a New Democracy: The Case of Spain" in Innovative Leaders in International Politics, Gabriel Sheffer, ed. Albany: State University of New York Press.

López Pintor, Rafael. 1982. La opinión pública española del franquismo a la democracia. Madrid: Centro de Investigaciones Sociológicas.

Maloney, William A. 1996. "The Market in Participation: Contracting out the Function." Paper presented at the conference on Social Capital and Democracy, Milan.

Maravall, José María. 1984. La política de la transición. Madrid: Taurus, 2nd. ed.

. 1995. Los resultados de la democracia. Madrid: Alianza.

Montero, José Ramón. 1981. "Partidos y participación política: Algunas notas sobre la afiliación política en la etapa inicial de la transición española." Revista de Estudios Políticos 23: 33-72.

Montero, Jose Ramón and Mariano Torcal. 1990. "Voters and Citizens in a New Democracy: Some Trend Data on Political Attitudes in Spain." International Journal of Public Opinion Research 2: 116-40.

Montero, José Ramón, Richard Gunther and Mariano Torcal. 1997. "Democracy in Spain: Legitimacy, Discontent, and Disaffection." Instituto Juan March, Madrid, Estudio/Working Paper 100. 
Morlino, Leonardo. 1995. "Political Parties and Democratic Consolidation in Southern Europe" in The Politics of Democratic Consolidation: Southern Europe in Comparative Perspective, Richard Gunther, P. Nikiforos Diamandouros, and Hans-Jürgen Puhle, eds. Baltimore: The Johns Hopkins University Press.

Moyser, George and Geraint Parry. 1996. "Voluntary Associations and Democratic Participation in Britain." Paper presented at the ECPR Joint Sessions, Oslo.

Newton, Kenneth. 1997. "Social Capital and Democracy." American Behavioral Scientist 40: 575-86. 1998. "Social and Political Trust," unpublished paper.

Nie, Norman, Sidney Verba, and Jae-On Kim. 1974. "Participation and the Political Cycle." Comparative Politics 6: 319-40.

Núñez, Clara Eugenia. 1992. La fuente de la riqueza: Educación y desarrollo económico en la España contemporánea. Madrid: Alianza.

Olson, Mancur. 1965. The Logic of Collective Action: Public Goods and the Theory of Groups. Cambridge: Harvard University Press.

Orizo, Francisco A. 1996. Sistemas de valores en la España de los 90. Madrid: Centro de Investigaciones Sociológicas.

Pérez Díaz, Víctor. 1996. España puesta a prueba, 1976-1996. Madrid: Alianza.

Price, R. 1989. "Trade Union Membership" in International Labour Statistics: A Handbook, Guide, and Recent Trends, R. Bean, ed. London: Routledge.

Prieto-Lacaci, Rafael. 1994. "Asociaciones voluntarias" in Tendencias sociales en España (1960-1990), Salustiano del Campo, ed., vol. I. Bilbao: Fundación BBV, 2nd. ed.

Putnam, Robert D. 1993. Making Democracy Work: Civic Traditions in Modern Italy. Princeton: Princeton University Press.

. 1995. "Bowling Alone: America's Declining Social Capital." Journal of Democracy 6: $65-78$.

Rosenstone, Steven J., and John Mark Hansen. 1993. Mobilization, Participation, and Democracy in America. New York: MacMillan.

Sabetti, Filipo. 1996. "Path Dependency and Civic Culture: Some Lessons from Italy about Interpreting Social Experiments." Politics and Society 24: 19-44.

Tarrow, Sidney. 1996. "Making Social Science Work across Space and Time: A Critical Reflection on Robert Putnam's Making Democracy Work." American Political Science Review 90: 389-97.

Torcal, Mariano. 1995. "Actitudes políticas y participación política en España: Pautas de cambio y continuidad." Universidad Autónoma de Madrid, PhD dissertation. 
1997. "Southern Europeans between Legitimacy and Disaffection: Attitudinal Change and Its Consequences in New Democracies." Paper presented at the XX International Congress of the Latin American Studies Association, Guadalajara, Mexico.

Van Deth, Jan W. 1996. "Social and Political Involvement: An Overview and Reassessment of Empirical Findings." Paper presented at the ECPR Joint Sessions, Oslo.

1997. "Introduction: Social Involvement and Democratic Politics" in Private Groups and Public Life: Social Participation, Voluntary Associations and Political Involvement in Representative Democracies, Jan W. Van Deth, ed. London: Routledge.

Weingast, Barry R. 1995. "The Economic Role of Political Institutions: Federalism, Markets, and Economic Development," Journal of Law, Economics and Organization 11: 1-31.

Whiteley, Paul F. 1996. "The Origins of Social Capital." Paper presented at the conference on Social Capital and Democracy, Milan.

1997. "Political Capital Formation among British Party Members" in Private Groups and Public Life: Social Participation, Voluntary Associations and Political Involvement in Representative Democracies, Jan W. Van Deth, ed. London: Routledge. 